\title{
Review Based Upon Ayurvedic and Traditional Uses of Cinnamomum tamala (Tejpatta)
}

\author{
Shifali Thakur, Bhawna Walia, Gitika Chaudhary* \\ Shuddhi Ayurveda Jeena Sikho Lifecare Pvt. Ltd. Zirakpur Punjab, India. \\ *Corresponding author's E-mail: shuddhi.research@jeenasikho.co.in
}

Received: 25-03-2021; Revised: 18-05-2021; Accepted: 25-05-2021; Published on: 15-06-2021.

\begin{abstract}
Cinnamomum tamala is an evergreen plant native to Sri Lanka and India. This herbal plant is commonly called Indian cassia, Tejpatta and Indian bay leaf. There are many bioactive constituents isolated from plant Cinnamomum tamala. Leaves of the plant possess aromatic fragrance and are also utilized as a flavoring agent. It is used in food curry, pickles and other spices. Besides food application, the leaves have also been used for curing a number of ailments. All parts of the plant possess many major bioactive chemical constituents like cinnamaldehyde, trans-cinnamaldehyde, 3,4,5,7-tetrahydroxyflavone, 3,3,4,5,6- pentahydroflavone (non-glycoside compounds), kaempferol, eugenol, etc. These phytochemical compounds have many pharmacological activities such as anticancer, antidiabetic, antimicrobial, hepatoprotective, antidiarrheal and immunomodulatory. In the past time, it is also considered for medicinal use. Their medicinal use was also mentioned in the literature of ayurveda, yunani and other traditional systems of medicine. Due to aromatic fragrance, it is also utilized in the perfume industry. The major aim of this review is to give a brief knowledge about the plant Cinnamomum tamala based on their phytochemical constituents, ayurvedic view, folk view and pharmacological application.
\end{abstract}

Keywords: Cinnamomum tamala, Tejpatta, Antidiabetic, Ayurveda, Eugenol.

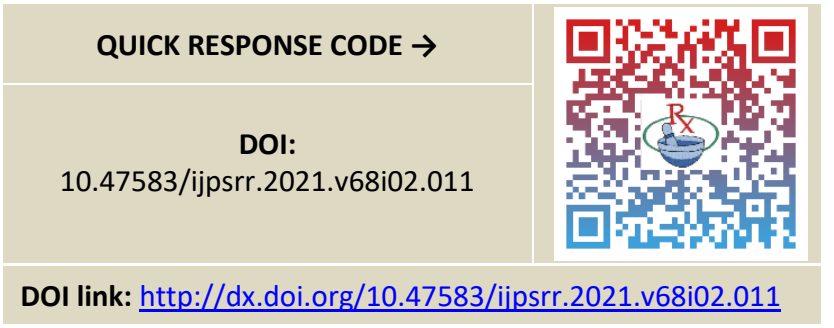

\section{INTRODUCTION}

ndia is a plant-based country and also famous for its spices production. Spices played a vital role in the history of exploration and development. Spices are widely utilized in meat, sauce, canning, frozen foods industries and food manufacturing industries. They are also utilized in the cosmetic and perfumery industries including their use in soap and toothpaste. The essential oils extracted from the spices are also used in various ayurvedic and allopathic formulations. Cinnamomum are known to be the oldest spices which have a sweet fragrance and warm taste. Cinnamomum tamala (Figure 1) is a plant that belongs to the Lauraceae family. It is locally named as Indian bay leaf and Tejpat. Cinnamomum is one of the genus which has been extensively utilized for the treatment of a wide array of disorders in various traditional systems of medicine including western herbal medicine ${ }^{1,2}$. C. tamala is used as a spice for cooking purposes across the world. The plant is native to India, Nepal, Bhutan and China. Cinnamomum family contains about 55 genera and over 2000 species worldwide ${ }^{3}$. The Himalayan region contains around eight species that is Cinnamomum bejolghota (Buch-Ham) Sweet, Cinnamomum comphora
(L.) J. presl, Cinnamomum glanduliferum (wall.) Meisn, Cinnamomum glaucescens (Nees) Hand-Mazz., Cinnamomum impressinervium Mesin., Cinnamomum parthenoxylon (Jack) Meism., Cinnamomum tamala (BuchHam) Nees and Eberm., and Cinnamomum zeylanicum Breyn. In all of the above species, C. tamala is reported for the improvement in digestion as well as appetite stimulation ${ }^{4}$. The suitable cultivation condition for the plant Cinnamomum tamala is a warm and tropical region. The plant is cultivated commercially in various areas of the country. In India, leaf production and essential oil of Cinnamomum tamala are utilized for commercial benefits. Many active components are isolated from the plant Cinnamomum tamala. Cinnamon bark oils were found to include cinnamaldehyde, eugenol and linalool. These compounds are reported to possess chemoprotective activity ${ }^{5}$. In ancient times various formulations were prepared from this plant like sudarshan choorna and chandraprabhavati ${ }^{6}$. It also possesses various pharmacological properties for the cure and prevention of many diseases. There are several phytochemicals responsible for their therapeutic action. These bioactive compounds are cinnamaldehyde, trans-cinnamaldehyde, 3,4,5,7- tetrahydroxyflavone, 3,3,4,5,7pentahydroxyflavone (non-glycoside compounds), kaempferol-3-O-rutinoside, quercetin-3-O-sophoroside (flavonoid glycoside), kaempferol-3,7 di-Orhamnopyraoside, $\alpha$-pinene, myrcene, camphene, $p$ cymene limonene, eugenol (4-hydroxy-3-methoxyallylbenzene), methyl ether eugenol and eugenol acetate $7,8,9$. Some reported studies showed that leaf oil of the plant also possesses many major bioactive compounds including Furanogermenone, $\beta$ - caryophyllene, 
germacerene $d$, curcumenol, curzerenone, furanodiene and furanodienone. These chemical compounds are reported to possess various pharmacological activity such as anti-hyperlipidemic, anti-diabetic activity, gastroprotective, anti-helminthic/ antiprotozoal activity, antidiarrhoeal, antifungal, antibacterial and others ${ }^{10}$. The vernacular names and taxonomical classification of $C$. tamala are shown in table no 1 and table no. 2 respectively.

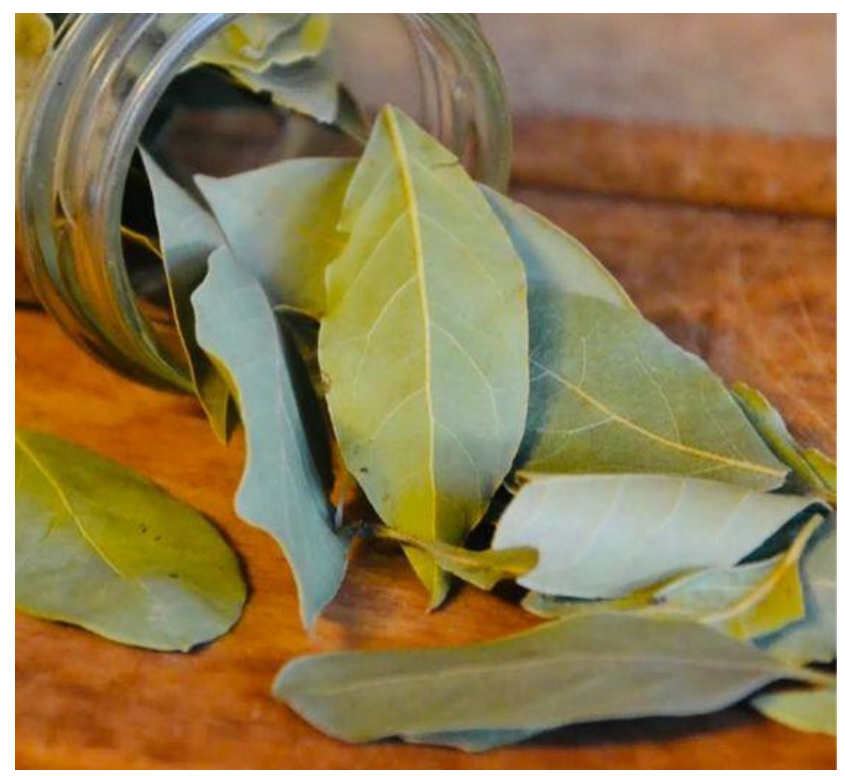

Figure 1. Cinnamomum tamala (Tejpatta)

Table 1: Vernacular Name of Cinnamomum tamala

\begin{tabular}{|l|l|}
\hline English & $\begin{array}{l}\text { Indian Bay Leaf, Indian cassia, Mlabar } \\
\text { Leaf, Indian Bark, Malabathrum }\end{array}$ \\
\hline Hindi & Tejpatta, Tejpatta and Tejpat \\
\hline Urdu & Tezpat \\
\hline Arabic & Saynamum tamalaam \\
\hline Japanese & Tamara-nikei, Tejipatto \\
\hline Chinese & Chai gui \\
\hline French & Laurier des Indes \\
\hline German & Indisches \\
\hline Burma & Thitchabo \\
\hline Nepal & Tejpatta, Sisi, Sinkauli \\
\hline Greek & Malabathron \\
\hline Sanskrit & Tamalpatra \\
\hline Marathi & Tamalpatra \\
\hline Tamil & Talishappattiri \\
\hline Assam & Tejpat \\
\hline Malayalam & Tamalapatram/ Karuntoli \\
\hline Telugu & Talisapatri \\
\hline Bengali & Tejpat \\
\hline Gujrati & Tamaal patra \\
\hline Tangkhul & Sakomna \\
\hline Kannada & Patraka \\
\hline Manipuri & Tejpat \\
\hline
\end{tabular}

Table 2: Botanical Classification of Cinnamomum tamala

\begin{tabular}{|l|l|}
$\begin{array}{l}\text { Taxonomical } \\
\text { classification } \\
\text { Kingdom }\end{array}$ & Taxon \\
\hline $\begin{array}{l}\text { Subkingdom } \\
\text { Division }\end{array}$ & $\begin{array}{l}\text { Tracheobionta (Vascular Plant) } \\
\text { Magnoliophyta }\end{array}$ \\
\hline Class & Magnoliopsida \\
\hline Order & Laurales \\
\hline Genus & Cinnamomum Schaeff \\
\hline Family & Lauraceae \\
\hline Species & $\begin{array}{l}\text { Cinnamomum tamala } \\
\text { Cinnamomum albiflorum Nees, } \\
\text { Common Name }\end{array}$ \\
\hline
\end{tabular}

\section{Botanical Description of C. tamala}

Cinnamomum tamala is a perennial small evergreen plant which is long up to 8-12 meter's height and a girth of $150 \mathrm{~cm}$. All parts of the plant possess various properties. The botanical description of the plant parts is discussed below:

Bark: The height of the plant is up to $7 \mathrm{~cm}$ and its branches up to $95 \mathrm{~cm}$ width, rugged bark changes its color from greenish-red to dark brown. The bark of the plant produces a mucllage/gum.

Leaves: Leaves of the plant are utilized as a spice and flavoring agent. Leave are thickened, pointed/acuminate ovate. It is $12-20 \mathrm{~cm}$ in length, $5-8 \mathrm{~cm}$ in width. Young leaves are reddish-pink and after some time leaves color changes into dark green that gives a glossy appearance. Leaves consist of a three nerves line from the base to the top. The taste of leaves is similar to the taste of clove and odor is like pepper.

Flower: The plant Cinnamomum tamala contains a small epicene flower, white in color and height up to $7.5 \mathrm{~mm}$. The twigs of the flower are long same as the calyx. Flowers are cross-fertilized by honey bees.

Fruit: The ripe fruit of Cinnamomum tamala is a dark purple, and ovate drupe (fruit with thin skin and they contain a seed). The plant contains a drupe long up to $13 \mathrm{~mm}^{11,12,13}$.

\section{Geographical Distribution of C. tamala}

The major area of the production of Cinnamomum tamala is Sri Lanka along with Seychelles, Madagascar and India ${ }^{14}$. The best quality of Cinnamomum bark is mainly as quills. It is produced in Sri Lanka in approx. 24000 ha and 3400 ha area ${ }^{15}$.

\section{Phytochemical Constituents of Cinnamomum tamala}

There is very little research work done on the phytochemicals of Cinnamomum tamala. The plant is reported to contain various chemotypes such as eugenol, cinnamaldehyde or cinnamaldehyde-linalool. The plant was reported to contain $41.2 \%$ to $55.19 \%$ cinnamaldehyde 
and $15.56-15.28 \%$ linalool from two types of sample collections i.e. natural and market-based analysis ${ }^{16}$. There are various marker phenylpropanoids such as (E)cinnamaldehyde, (Z)- cinamaldehyde, (E)- cinnamyl alcohol, eugenol, hydrocinnamyl acetate, (Z)- cinnamyl acetate, (Z)-cinnamic acid and (E)-cinnamyl acetate have been also reported from Cinnamomum tamala oils. Eugenol and Cinnamaldehyde are the active biochemicals formed from shikimic acid pathway while linalool is formed from mevalonic acid. Similarly, cinnamaldehyde is reported to be directly formed by the first year reduction of cinnamic acid, which is a part of phenylalanine pathway. (Z)-Cinnamic acid was only found in the oils of the first-year samples of Cinnamomum tamala ${ }^{17,18}$. Some scientific research was comparable in terms of major compound cinnamaldehyde reported in Cinnamomum tamala ${ }^{19,20}$. Earlier phytochemical studies have revealed the presence of important compounds such as eugenol 21, cinnamaldehyde ${ }^{22,23}, \beta$-caryphyllene and linalool, transsabinene hydrate, (Z)- $\beta$-ocimene, myrcene, $\alpha$-pinene and $\beta$-sabinene, germacrene $A$ and $\alpha$-gurjunene ${ }^{24}$. Cinnamomum leaf contains three flavonoid compounds named as quercetin, laempferol and quercetrin. These are responsible for antioxidant activity ${ }^{25,26}$.

Showkat et al., reported the chemical constituents from essential oil of Cinnamomum tamala and other constituents were evaluated earlier. Eugenol was reported as a major chemical constituent in Cinnamomum tamala. Reported studies demonstrated, the chemical composition of the essential oils obtained from the leaves of $C$. tamala was determined by Gas-Chromatography Mass spectrometry. The yield of the oil on a dry weight basis ranged from $1.2 \%$ to $3.9 \%(\mathrm{w} / \mathrm{w})$. Phenyl propanoids (88.9$95.0 \%)$ is the major portion of the oils. Firstly, eugenol (41.8-91.4\%) was the active compound that followed by eugenyl acetate $(0.0-47.1 \%)$ and $\alpha$-phellandrene (0.6$2.5 \%$ ) in the analysed oils ${ }^{27}$. A study reported that the GSMS analysis showed the presence of eighty-one components from Cinnamom leaf volatile oil representing $94.1 \%$ of the total amount and eugenol $(66.1 \%)^{28}$.

\section{Traditional and Modern View}

A. Ayurvedic View: Cinnamomum tamala is also known as Tejpatta and Indian Bay leaf. Tejpatta is utilized to impact a characteristic flavor in various dishes. In India, it is used in various cuisines because of its peppery, clove-cinnamonlike flavor. The plant species is also beneficial for various medicinal uses. Some Ayurvedic studies reported that Tejpatta is useful for diabetes as it helps to manage blood glucose levels by enhancing insulin secretion due to its antioxidant property. According to Ayurveda, diabetes is caused due to an aggravation of Vata (Air compound) and impaired digestion. Impaired digestion leads to an accumulation of Ama (toxic remains in the body due to improper digestion) in the pancreatic cells and impairs the function of insulin. Tejpatta has hot potency that promotes healthy digestion and reduces Ama (fire produced in the stomach). Tejpatta helps to lower the bad cholesterol and maintains blood pressure by removing excessive sodium due to its diuretic property. Therefore, Tejpatta is also beneficial for heart health. Rasa Panchak of Tejpatta is mentioned in table no. 3 below ${ }^{29,30}$.

Table 3: Rasa Panchak of Tejpatta (Cinnamomum tamala)

\begin{tabular}{|l|l|}
\hline Sanskrit/English & Sanskrit/English \\
\hline Rasa/ Taste & $\begin{array}{l}\text { Tikat, katu/ Astringent, } \\
\text { bitter }\end{array}$ \\
\hline $\begin{array}{l}\text { Virya/Potency } \\
\text { Vipaka/ Methabolic } \\
\text { Property } \\
\text { Guna/ Physical Property }\end{array}$ & $\begin{array}{l}\text { Madhur/Sweet } \\
\text { Laghu,Tikshan/Little, } \\
\text { Pungent }\end{array}$ \\
\hline
\end{tabular}

According to Ayurveda, Tejpatta balances all the Dosha (Disorder) i.e. Vata (Air component), Pitta (Fire+Water), and Kapha Dosha (Earth+Water) of human body.

\section{Various benefits and uses of Tejpatta (Cinnamomum tamala)}

1. Tejpatta is an effective herb for the treatment of the common cold. It controls cough, releases mucus and cleanes the air passages because of its Kapha balancing property. It is suggested to swallow with water or honey after lunch and dinner to treat common cold and cough .

2. According to Ayurveda, the main Doshas (Disorders) involved in Asthma are Vata and Kapha. An aggravated Vata dosha imbalances the Kapha dosha in the lungs. This produces an obstruction in the air passages that makes breathing tough. Tejpatta helps to remove extra mucus from the lungs by melting it due to its hot potency which helps for the treatment of asthma ${ }^{31}$.

3. There are many scientific evidence present to support the role of Tejpatta for bad breath.

4. Tejpatta leaf oil is rich in good constituents. These chemical constituents showed good enzyme activity that helps in melanin production. Tejpatta is also beneficial against wound infections. 2-5 drops of tejpatta oil mixed with coconut oil is suggested for eczema-like skin disorder ${ }^{32,33}$.

Some formulation of Tejpatta are citrakkadi Taila, kasisadi Taila and vajraka Taila

B. Folk View: Cinnamomum tamala plant is utilized many years ago in the Indian medicinal system, Ayurvedic system and also the folk system for its therapeutic activity. The Sanskrit name of Tejpatta is 'Tamalapattra' which means 'dark leaf' although that seems to be poorly motivated. The Greek traders took that name to their language, but later it is identified Sanskrit word as a plural form with a definite article, (ta) malabathra for which they back formed to a singular malabathron. Malabathrun or Malobathrum was taken by Romans. Ancient literature revealed that dried leaves and bark of Tejpatta were prescribed for fever, anemia and body odour. Tejpatta is utilized for its aromatic fragrance. Apart from flavoring agent it is also used as a 
mouth refresher and used in chewing gums. Folk people used Tejpatta powder for some dental problems like reducing tooth pain. The plant is useful for the treatment of many diseases and disorders including colon cancer, diabetes, cardiac diseases, CNS disorders and bleeding disorders (useful for increasing blood circulation in the uterus) and it is also beneficial in appetite problem, mouth problems like dryness, unpleasant /poor breath problem and rheumatism ${ }^{34}$.

\section{Modern View}

Many issues are faced by the Global herbal drug industry in today's scenario mostly the practice of making these drugs adulterated. This is the major reason why people lost faith in these herbal drugs nowadays 35,36,37,38,39,40. In today's time, intentional adulteration is practiced in many different ways like by substituting standard commercial variety, by substituting superficially similar but inferior drugs, by substituting artificially manufactured drugs, the substitution of exhausted drugs and by substituting toxic materials. Adulteration can be either intentional or unintentional. These adulteration processes ultimately degrade the quality of the original drugs. The herbal plant vendors use these adulteration techniques so smartly that these remain undetectable until and unless examination on a microscopic level and chemical level are implied ${ }^{41,42,43}$. The major disadvantages associated with adulteration are deterioration and degradation of drugs. Adulteration also increases the cost of drugs and produces adverse effects instead of showing actual biological affect ${ }^{44,45}$. The traditional herbal drugs and their formulations are associated with negligible toxicity and are free from any kind of adulteration ${ }^{46}$. Traditional Ayurvedic herbal formulations of Tejpatta plants are associated with a wide range of medicinal properties too which cures a variety of ailments without causing any severe harm to the human body. Health risks are usually associated with modern adulterated drugs. For instance, the modern anti-diabetic drugs have side effects associated with them whereas the anti-diabetic activity of Cinnamomum tamala is well demonstrated by many studies where the least toxicity and adverse effects were observed. Commercially, Cinnamomum tamala is utilized as a flavouring agent and plant leaves are utilized for medicinal uses ${ }^{47}$.

\section{Reported Therapeutic and Pharmacological Studies of Cinnamomum tamala}

Various studies have been conducted on this plant to know its pharmaceutical and therapeutic uses. Large-scale clinical studies are still needed to prove the clinical efficacy of this herb, especially in skin diseases, immunomodulatory disorders and diabetes. Some reported studies on this plant are shown in table no. 4.

1. Antioxidant Activity: Gupta and Sharma have reported the antiperoxidative effect of ethanolic extract of Cinnamomum tamala leaves on ferrous sulfate-induced lipid peroxidation in isolated rat liver homogenate. It was determined by Thiobarbituric Acid Reactive Substances assay. The result showed significant antiperoxidative effects in the models ${ }^{48}$. Prasad et al., investigated that the leaves of five species of Cinnamomum including $C$. tamala have antioxidant properties. Results showed that $C$. tamala exhibited higher superoxide anion scavenging than others. Singh et al., reported that the volatile oil and acetone extract of Cinnamomum tamala leaves possesses strong radical scavenging activity ${ }^{49}$. Bajpai et al., reported that the total polyphenols content and water extract of leaves of Cinnamomum tamala possess antioxidant activity ${ }^{50}$. The antioxidant activity was determined by $\beta$ carotene linoleic acid auto-oxidation assay.

2. Antidiabetic activity: Sharma et al., investigated the hypoglycaemic and antihyperglycemic activity of $50 \%$ ethanolic extract of C. tamala leave in normal and streptozotocin-induced hyperglycemic rats. The observation showed that the blood glucose level of untreated rats decreased from 69.3 to $64.2 \mathrm{mg} / 100 \mathrm{ml}$ after 12 hours, and for those treated with the extract of $C$. tamala at doses of 100, 250 and $500 \mathrm{mg} / \mathrm{kg}$ the blood glucose declined from $68.1-69.5$ to $42.9-49.1 \mathrm{mg} / 100 \mathrm{ml}$ over the same period ${ }^{51}$. Dhaliwal et al., reported that one antidiabetic formulation containing epicatechin and gymnemic acid as major active constituents and Cinnamomum leaves along with it too resulted in the production of insulin in human pancreas ${ }^{52}$. Kar et al., investigated that the ethanolic extract of $C$. tamala leaves has been found to lower blood glucose in alloxan diabetic albino rats after two weeks of treatment. The result showed a significant reduction of blood glucose levels in rats ${ }^{53}$. Pushpangadan and Prakash patented an herbal nutraceutical formulation in 2006 to provide health benefits to diabetes patients. The formulation includes powder/extract of C. tamala leaves as an essential component along with other herbs ${ }^{54}$. Chakraborty and Das investigated the antidiabetic and antioxidant activity of aqueous extract of Cinnamomum tamala leaves. Diabetes was induced in albino rats by the treatment with streptozotocin. The C. tamala extract was administrated for three weeks in rats. Hence, $C$. tamala extract was found to be potent for balancing blood glucose levels in the models 55

3. Anticancer Activity: Saluja et al., investigated the anticancer activity of Cinnamomum tamala leaf extract against Ehrlich ascites carcinoma (EAC) in Swiss albino mice. The ethanolic and acetone extract of Cinnamomum tamala leaves were found to be significant for the anticancer activity in the mice ${ }^{56}$.

4. Hepatoprotective Activity: ThamizhSelvam et al., reported hepatoprotective activity of methanolic extract of $C$. tamala leaves against paracetamol-induced toxicity in Swiss albino mice. Hepatic injury caused a rise of cellular enzymes in plasma. Mice was treated with $C$. tamala extract at doses of 100 and $200 \mathrm{mg} / \mathrm{kg}$ for eight days. Higher hepatoprotective activity was observed when model was treated with $200 \mathrm{mg} / \mathrm{kg}$ of dose ${ }^{57}$. 
5. Anti-inflammatory Activity: Gambhire et al., reported the anti-inflammatory effect of aqueous extract of leaves of Cinnamomum tamala. The extract was found to significantly inhibit the carrageenam-induced paw edema in mice. The dose of $400 \mathrm{mg} / \mathrm{kg}$ was administrated in the mice. The results showed inhibition of about $54.4 \%$ against edema in the mice model ${ }^{58}$.

6. Effect on Gastro-Intestinal Tract: Eswaran et al., investigated the gastroprotective activity of $C$. tamala leaf extract in rats. Models were administrated with the extract of C. tamala in the doses of 50,100 and $200 \mathrm{mg} / \mathrm{kg}$ twice daily for five days to protect against ethanol, cold restraint stress and pylorus ligation-induced ulcers. The results showed a significant reduction in lesion index in the models 59 .

7. Antidiarrheal Activity: Rao et al., examined the antidiarrheal activity of $50 \%$ ethanolic extract of C. tamala leaves in the rats. The extract was administrated orally in doses of 25,50 and $100 \mathrm{mg} / \mathrm{kg}$. Result showed a significant reduction in castor oil-induced diarrhoea. A dose of 100 $\mathrm{mg} / \mathrm{kg}$ resulted in a significant reduction in a gastrointestinal fluid produced in rats ${ }^{60}$.

8. Antimicrobial Activity: Yadav et al., investigated that Cinnamomum tamala have fungicidal/fungistatic activity. The essential oils of Cinnamomum tamala leaf have been found to inhibit the growth of two ringworm fungi, Trichophyton mentagrophytes and Microsporum audounil. The minimum 500 ppm of concentration of essential oil of C. tamala inhibited fungal growth in poisoned food method. In this method, the test dose was mixed in the culture medium. The essential oil showed better effectiveness as compared to some synthetic antifungal agents ${ }^{61}$. Methmood et al., reported antimicrobial activity of alcoholic extract of $C$. tamala leaves against Trichophyton rubrum, Microsporum gypseum and Epidermophyton floccosum. An inhibition zone was also observed against Candida albicans with alcoholic extract
62. Kapoor et al., reported antifungal activity of volatile oil and oleoresins from Cinnamomum tamala leaf against some fungi like Apergillus niger, A. Flavans, A. salani etc. Oleoresins were showing less inhibition as compared to volatile oil ${ }^{63}$. De et al., tested the antimicrobial activity of 35 Indian spices in which fifteen spices were found to possess antimicrobial activity. The leaf extract of $C$. tamala has been found to inhibit the growth of Saccharomyces cervisiae ${ }^{64}$. Singh et al., reported antibacterial activity of volatile oils and acetone extract of $C$. tamala leaves against E. coli, Salmonella typhi, Pseudomonas aeruginosa, Bacillus cereus, Bacillus subtilis and Staphylococcus aureus ${ }^{65}$.

9. Effect on Immune system: Chaurasia et al., reported immunosuppressive effect of hexane fraction of leaves of Cinnamomum tamala in rats. Rats were sensitized with Sheep red blood cells and administered $C$. tamala extract at 400,800 , and $1600 \mathrm{mg} / \mathrm{kg}$ body weight. For standard cyclophosphamide was used in the rats. After seven days, the extract of $C$. tamala inhibited the hypersensitivity in rats whereas no inhibition was found when models treated with cyclophosphamide ${ }^{66}$.

10. Miscellaneous Activity: Karerat et al., tested dried Cinnamomum tamala leaf powder/extract along with several other plant components against the poisonous effect of tobacco smoking. Some herbal formulations include powder extract of $C$. tamala which acts against addiction to tobacco-related products ${ }^{67}$. Palpu et al., have patented an Ayurvedic herbal soft drink with immunity enhancing, hepatoprotective, antifatigue, antioxidant and antistress activity. The formulation includes decoction of leaves of Cinnamomum tamala ${ }^{68}$. Abbas et al., reported the nematicidal effect of Cinnamomum tamala leaf extract against Meloidogyne javanica. Ethanolic extract of leaves at $1000 p p m$ concentration was found to be significant for inhibition of egg hatching of the nematode Meloidogyne javanica ${ }^{69}$. Some of reported pharmacological activities are shown in table no. 4.

Table 4: Reported experimental and Clinical studies of Cinnamomum tamala

\begin{tabular}{|c|c|c|c|c|}
\hline $\begin{array}{l}\text { Sr. } \\
\text { No. }\end{array}$ & Extract & $\begin{array}{l}\text { Method } \\
\text { In-vivo / In-vitro }\end{array}$ & $\begin{array}{l}\text { Pharmacological } \\
\text { Activity }\end{array}$ & References \\
\hline 1. & Ethanolic Extract & Rat model & Antioxidant & 48 \\
\hline 2. & Ethanolic Extract & Diabetic Rat model & \multirow[t]{3}{*}{ Antidiabetic } & \multirow[t]{3}{*}{$51,53,55$} \\
\hline 3. & Ethanolic Extract & Albino rats & & \\
\hline 4. & Aqueous Extract of leaves & Albino rats & & \\
\hline 5. & Leaf Extract & Swiss Albino Mice & Anticancer & 56 \\
\hline 6. & Methanolic Extract & Swiss Albino Mice & Hepatoprotective & 57 \\
\hline 7. & Aqueous Extract & Mice & Anti-inflammatory & 58 \\
\hline 8. & Leaf oil & $\begin{array}{l}\text { Trichophyton mentagrophytes and } \\
\text { Microsporum audounil. }\end{array}$ & \multirow[t]{2}{*}{ Anti-fungal } & \multirow[t]{2}{*}{61,62} \\
\hline 9. & Alcoholic Extract & $\begin{array}{l}\text { Trichophyton rubrum, Microsporum } \\
\text { gypseum and Epidermophyton floccosum }\end{array}$ & & \\
\hline 10. & $\begin{array}{l}\text { Volatile oil \& Acetone } \\
\text { extract }\end{array}$ & $\begin{array}{l}\text { E. coli, Salmonella typhi, Pseudomonas } \\
\text { aeruginosa, Bacillus cereus, Bacillus } \\
\text { subtilis and Staphylococcus aureus }\end{array}$ & Antibacterial & 63 \\
\hline 11. & Leaf Extract & Rat model & Immunomodulatory & 67 \\
\hline
\end{tabular}




\section{CONCLUSION}

Herbal plants have been played a significant role in maintaining the health of the community since past times. Cinnamomum tamala (tejpatta) is one of the most commonly used spices in Indian food. This plant also possesses various therapeutic activities. All parts of the plant possess many major bioactive chemical constituents like Cinnamaldehyde, trans-cinnamaldehyde, 3,4,5,7tetrahydroxyflavone, 3,3,4,5,6- pentahydroflavone (nonglycoside compounds), kaempferol, eugenol etc. These phytochemicals are useful for the treatment of various diseases or disorders such as cancer, diabetes, ulcer, gastrointestinal infections and possess many pharmacological activities like anti-diabetic, antiinflammatory, anti-microbial, antidiarehoeal, anti-fungal and hepatoprotective activity. Many reported studies are suggested that Cinnamomum tamala possessed a wide range of benefits in diabetic problem. Clinical researches are also required to know other pharmacological activities of Cinnamomum tamala so in this review article authors tried to compile all the reported Ayurvedic and pharmacological properties of the plant.

\section{REFERENCES}

1. Khan AR, Hossain M. LEAF-BLIGHT OF BAY-LEAF PLANTS, CAUSED BY GLOMERELLA-CINGULATA, IN BANGLADESH. Bangladesh Journal of Botany. 1985 Dec 1;14(2):181-2.

2. Sharma SR, Dwivedi SK, Swarup D. HYPOGLYCAEMIC EFFECT OF SOME INDIGENOUS MEDICINAL PLANTS IN NORMOGLYCAEMICRATS. Indian journal of animal sciences. 1996;66(10):1017-20.

3. Yadav P, Dubey NK. Screening of some essential oils against ringworm fungi. Indian Journal of Pharmaceutical Sciences. 1994;56(6).

4. Imani A, Bani MS, Noori F, Farzaneh M, Moghanlou KS. The effect of bentonite and yeast cell wall along with cinnamon oil on aflatoxicosis in rainbow trout (Oncorhynchus mykiss): Digestive enzymes, growth indices, nutritional performance and proximate body composition. Aquaculture. $2017 \mathrm{Jul}$ 1;476: 160-7.

5. Mehta S, Purohit VK, Andola HC. Pharmacological Activities of Cinnamomum tamala Nees \& Eberm. and Medical Implication: A Review. Medicinal \& Aromatic Plants. 2014;3(4):1-6.

6. Rani A, Pande C, Tewari G, Patni K. A review on aroma profile of Cinnamomum species in North and North East India.

7. Tiwari S, Saxena S, Kumar R. Process Scale Up of Ibrufen Tablet. Journal of Pharmaceutical Sciences and Research. 2011 Oct 1;3(10):1525.

8. Rao PV, Gan SH. Cinnamon: a multifaceted medicinal plant. Evidence-Based Complementary and Alternative Medicine. 2014 Oct;2014.

9. Patley C, Sagar R, Patley R, Singh N, Singh M. Investigating the Wound Healing Effect of Cinnamomum tamala Leaves in Diabetic Rats. International Journal of Pharmacy and Drug Research. 2017; 3:1-5.
10. Gambhire MN, Juvekar AR, Wankhede SS. Anti-inflammatory activity of aqueous extract of Cinnamomum tamala leaves by in vivo and in vitro methods. Journal of Pharmacy Research. 2009 Sep;2(9):1521-4.

11. Tiwari S, Talreja MS, Pandey MS. A REVIEW ON USE OF NOVEL DRUG DELIVERY SYSTEMS IN HERBAL MEDICINES.

12. Nirmala Nithya $R$, Shanmathi $S$, Rohini M, Sekar Babu Hariram AP, Sindhu S. Research Journal of Pharmaceutical, Biological and Chemical Sciences.

13. Soni R, Mehta NM, Srivastava DN. Effect of ethanolic extract of Cinnamomum tamala leaves on wound healing in stz induced diabetes in rats. Asian. J. Pharm. Clin. Res. 2013;6:3942.

14. De Guzman CC, Siemonsma JS. Plant Resources of South East Asia, No. 13, Spices. Backhys Pub., Lieden. 1999.

15. Coppen JJW. Flavours and Fragrances of Plant Origin, FAO, Rome. 1995.

16. Gulati BC, Agarwal SG, Thappa RK, Dhar KL. Essential oil of Tejpat (Kumaon) from Cinnamomum tamala. Indian Perfum. 1977;21:15-20.

17. Husain A, Virmani OP, Sharma A, Kumar A, Misra LN. Major essential oil-bearing plants of India. Major essential oilbearing plants of India.. 1988.

18. Sood RP, Padha CD, Talwar YP, Jamwal RK, Chopra MM, Rao PR. Essential oils from the leaves of Cinnamomum tamala Nees and Eberm growing in Himachal Pradesh. Indian Perfumer. 1979;23(2):75-8.

19. Liangfeng Z, Yonghua L, Baoling L, Biyao L, Nianhe X. Aromatic Plants and Essential Constituents: Supplement 1. Hai Feng Publishing; 1995.

20. Formacek V, Kubeczka KH. Essential oils analysis by capillary gas chromatography and carbon-13 NMR spectroscopy. Chichester, John Wiley \& Sons; 1982.

21. Dighe VV, Gursale AA, Sane RT, Menon S, Patel PH. Quantitative determination of eugenol from Cinnamomum tamala nees and eberm. Leaf powder and polyherbal formulation using reverse phase liquid chromatography. Chromatographia. 2005 May;61(9):443-6.

22. Mehta S, Purohit VK, Andola HC. Pharmacological Activities of Cinnamomum tamala Nees \& Eberm. and Medical Implication: A Review. Medicinal \& Aromatic Plants. 2014;3(4):1-6.

23. Chauhan NK, Haider SZ, Lohani H, Sah S, Yadav RK. Quality evaluation of Cinnamomum tamala Nees collected from different locations of Uttarakhand. J Non-Timber Products. 2009;16:191-4.

24. Mir SR, Ali M, Kapoor R. Chemical composition of essential oil of Cinnamomum tamala Nees et Eberm. leaves. Flavour and fragrance journal. 2004 Mar;19(2):112-4.

25. Prasad KN, Yang B, Dong X, Jiang G, Zhang H, Xie H, Jiang Y. Flavonoid contents and antioxidant activities from Cinnamomum species. Innovative Food Science \& Emerging Technologies. 2009 Oct 1;10(4):627-32.

26. Sultana S, Ripa FA, Hamid K. Comparative antioxidant activity study of some commonly used spices in Bangladesh. Pakistan journal of biological sciences. 2010 Apr 1;13(7):340. 
27. Rana VS, Langoljam RD, Verdeguer M, Blázquez MA. Chemical variability in the essential oil of Cinnamomum tamala $\mathrm{L}$. leaves from India. Natural product research. 2012 Jul 1;26(14):1355-7.

28. Kapoor IP, Singh B, Singh G, Isidorov V, Szczepaniak L. Chemistry, antimicrobial and antioxidant potentials of Cinnamomum tamala Nees \& Eberm (Tejpat) essential oil and oleoresins.

29. Sharma P.V. DravyagunaVijnana. Chaukambha Bharti Academy, Varanasi. 2019.

30. Mudgal D. DravyagunVijnana. Ayurvedic Sanskrit Hindi Pustak Bhandar. 2019.

31. Upadhyay RK. Therapeutic and Pharmaceutical Potential of Cinnamomum tamala.RRJPPS.2017;6(3):18-28.

32. Bendre AV, Tare MS, Kamble KV, et al. Diuretic activity of Cinnamomum tamala. Research Journal of Pharmacy and Technology. 2010;3(1):289-290.

33. Shah M, Panchal M. Ethnopharmacological properties of Cinnamomum tamala- A review. 2010;5(3):141-144.

34. Kumar S, Vasudeva N, Sharma S. Pharmacological and pharmacognostical of Cinnamomum tamala Nees \& Eberm. JPRS.2012;5(1):480-484

35. Jain A, Dubey M, Gupta A, Mahajan S, Chaudhari HS Antimicrobial activity of Cinnamomum tamala (Tejpat) against some bacterial and fungal pathogens. Journal of Pharmacy Research. 2011 Nov;4(11):3975-7.

36. Ullah N, Khan MA, Khan T, Ahmad W. Protective effect of Cinnamomum tamala extract on gentamicin-induced nephrotic damage in rabbits. Tropical Journal of Pharmaceutical Research. 2013 May 9;12(2):215-9.

37. Tewari NN. Some crude drugs: source, substitute and adulterant with special reference to KTM crude drug market. Sachitra Ayurved. 1991.

38. Shukla P, Pawar RM. OA01. 22. Quality aspect and variability observed in physico-chemical characteristics and mineral content of ayurvedic herbo mineral formulations from Indian market. Ancient Science of Life. 2012.

39. Sunita G. Substitute and adulterant plants. Substitute and adulterant plants.1992.

40. Uniyal MR, Joshi GC. Historical view of the basic principles of the identification of controversial drugs, problems and suggestions. Sachitra Ayurved. 1993.

41. Saraswathy A. Adulterants and substitutes in Ayurveda. Sachitra Ayurved. 2001.

42. Gupta AK. Quality standards of Indian medicinal plants. Volume 1. Quality standards of Indian medicinal plants. Volume 1.2003

43. Monika, Kaushal K. Adulteration in Ayurvedic Raw Herbs. International Journal of Science and Research. 2015.

44. Afaq SH. A comparative introduction of the Unani and Tibetan medical traditions. Ayur Vijnana. 1999.

45. Mitra SK, Kannan R. A note on unintentional adulterations in Ayurvedic herbs. Ethnobotanical Leaflets. 2007.

46. More DB, Giradkar PS. Herbal Drug Adulteration: A Hindrance to the Development of Ayurveda Medicine.
47. Thakur S., Choudhary S., Kumari I., Sudan M., et al. Datura (Datura metel): a review based upon its Ayurvedic perspective. International Journal of current research. Vol. 13, issue, 02, pp.16302-16309, February, 2021

48. Gupta V, Sharma M. Protective effect of Cinnamomum tejpata on lipid peroxide formation in isolated rat liver homogenate. Curr Res J Biol Sci. 2010 Jul 20;2:246-9.

49. Singh VP, Pandey R, Yadav B, Pandey VB. Flavonoids of Cinnamomum tamala. Natural Product Sciences. 2002;8(1):16-7.

50. Bajpai M, Pande A, Tewari SK, Prakash D. Phenolic contents and antioxidantactivity of some food and medicinal plants. International journal of food sciences and nutrition. $2005 \mathrm{Jan}$ 1;56(4):287-91.

51. Sharma SR. Hypoglycaemic and hypolipidemic effects of Cinnamomum tamala Nees leaves. Indian J Exp Biol. 1996;34:372-4.

52. Dhaliwal KS. Method and composition for treatment of diabetes 1999. US Patent.;5886029.

53. Kar A, Choudhary BK, Bandyopadhyay NG. Comparative evaluation of hypoglycaemic activity of some Indian medicinal plants in alloxan diabetic rats. Journal of ethnopharmacology. 2003 Jan 1;84(1):105-8.

54. Pushpangadan P, Prakash D, inventors; Council of Scientific, Industrial Research (CSIR), assignee. Herbal nutraceutical formulation for diabetics and process for preparing the same. United States patent US 7,014,872. 2006 Mar 21.

55. Chakraborty $\mathrm{U}$, Das H. Antidiabetic and antioxidant activities of Cinnamomum tamala leaf extracts in STZ-treated diabetic rats. Global Journal of Biotechnology \& Biochemistry. 2010;5(1):12-8.

56. Saluja MS, Sangameswaran B, Sharma A. Cytotoxic activity of Cinnamomum tamala linn against ehrlich ascites carcinoma (EAC) in mice. The Pharma Research. 2010;3:232-42.

57. Thamizhselvam N, Krishna Yathi K, Sanjaya Kumar YR, Saraswathy VN, Venugopalan TN, Jaya N. Hepatoprotective activity of methaolic extract of Cinnamomum tamala (Nees) against paracetamol Intoxicated Swiss Albino mice. IJPWR. 2010;1(2):1-3.

58. Gambhire MN, Juvekar AR, Wankhede SS. Anti-inflammatory activity of aqueous extract of Cinnamomum tamala leaves by in vivo and in vitro methods. Journal of Pharmacy Research. 2009 Sep;2(9):1521-4.

59. Eswaran MB, Surendran S, Vijayakumar M, Ojha SK, Rawat AK, Rao CV. Gastroprotective activity of Cinnamomum tamala leaves on experimental gastric ulcers in rats. Journal of Ethnopharmacology. 2010 Mar 24;128(2):537-40.

60. Rao CV, Vijayakumar M, Sairam K, Kumar V. Antidiarrhoeal activity of the standardised extract of Cinnamomum tamala in experimental rats. Journal of natural medicines. 2008 Oct;62(4):396-402.

61. Yadav, P. and Dubey, N. K. Screening of some essential oils against ringworm fungi. Indian J. Pharm. 1994. Sci. 56(6):227230.

62. Mehmood Z, Ahmad I, Mohammad F, Ahmad S. Indian medicinal plants: a potential source for anticandidal drugs. Pharmaceutical Biology. 1999 Jan 1;37(3):237-42. 
63. Kapoor IP, Singh B, Singh G, Isidorov V, Szczepaniak L. Chemistry, antimicrobial and antioxidant potentials of Cinnamomum tamala Nees \& Eberm.(Tejpat) essential oil and oleoresins.

64. De M, Krishna De A, Banerjee AB. Antimicrobial screening of some Indian spices. Phytotherapy Research: An International Journal Devoted to Pharmacological and Toxicological Evaluation of Natural Product Derivatives. 1999 Nov;13(7):616-8.

65. Singh G, Maurya S, Marimuthu P, Murali HS, Bawa AS. Antioxidant and antibacterial investigations on essential oils and acetone extracts of some spices.

66. Chaurasia JK, Pandey N, Tripathi YB. Effect of hexane fraction of leaves of Cinnamomum tamala Linn on macrophage functions. Inflammopharmacology. 2010 Jun;18(3):147-54.
67. Karerat AK, Ifthikar OR, Varghese J, Vellappillil AV, Palpu P, Rawat AK, Rao CV, Govindarajan R, inventors; Council of Scientific, Industrial Research (CSIR), assignee. Anti-cigarette herbal formulation as an antidote to tobacco. United States patent US 7,534,454. 2009 May 19.

68. Palpu P, Mehrotra S, Rawat AK, Khatoon S, Ojha SK, Rastogi S, Srivastava M, Seth PK, Agarwal AK, Kakkar P, Anand M, inventors. Herbal soft drink. United States patent US 7,550,163. 2009 Jun 23.

69. Abbas S, Dawar S, Tariq M, Zaki MJ. Nematicidal activity of spices against Meloidogyne javanica (Treub) Chitwood. Pakistan Journal of Botany. 2009 Oct 1;41(5):2625-32.

Source of Support: The author(s) received no financial support for the research, authorship, and/or publication of this article.

Conflict of Interest: The author(s) declared no potential conflicts of interest with respect to the research, authorship, and/or publication of this article.

For any question relates to this article, please reach us at: editor@globalresearchonline.net New manuscripts for publication can be submitted at: submit@globalresearchonline.net and submit_ijpsrr@rediffmail.com 